\title{
In Vivo Diuretic Activity of Hydromethanolic Extract and Solvent Fractions of the Root Bark of Clerodendrum myricoides Hochst. (Lamiaceae)
}

\author{
Gebrelibanos Gebremichael Welu, ${ }^{1,2}$ Ebrahim M. Yimer ${ }^{D},{ }^{3}$ Haftom Gebregergs Hailu, ${ }^{1}$ \\ Dayananda Bhoumik, ${ }^{1}$ and Mehari Meles Lema ${ }^{4}$ \\ ${ }^{1}$ Department of Pharmacology and Toxicology, College of Health Sciences, Mekelle University, Mekelle, Ethiopia \\ ${ }^{2}$ Pharmacy and Toxicology Unit, Department of Pharmacy, College of Health Sciences, Aksum University, Aksum, Ethiopia \\ ${ }^{3}$ Department of Pharmacy, College of Medicine and Health Sciences, Wollo University, Dessie, Ethiopia \\ ${ }^{4}$ Ethiopian Public Health Institute, Addis Ababa, Ethiopia
}

Correspondence should be addressed to Ebrahim M. Yimer; ebrahim99muhammed@gmail.com

Received 5 June 2020; Revised 26 October 2020; Accepted 30 November 2020; Published 10 December 2020

Academic Editor: Fadia S. Youssef

Copyright (C 2020 Gebrelibanos Gebremichael Welu et al. This is an open access article distributed under the Creative Commons Attribution License, which permits unrestricted use, distribution, and reproduction in any medium, provided the original work is properly cited.

\begin{abstract}
Introduction. Clerodendrum myricoides (Lamiaceae) has been traditionally used for the treatment of various ailments, including body swelling and urine retention. The present study aimed to evaluate the diuretic activity of a crude extract and solvent fractions of the root bark of C. myricoides. Methodology. The coarsely powdered root bark of C. myricoides was extracted by a cold maceration method using $80 \%$ methanol. A portion of the extract was fractionated based on the polarity index of solvents to obtain chloroform, ethyl acetate, and aqueous fractions. To investigate the diuretic activity of the plant, rats were divided into fifteen groups. The normal control groups received either water or $2 \%$ tween 80 , the standard group received furosemide (10 mg/ $\mathrm{kg}$ ), and the test groups were administered the hydromethanolic extract and solvent fractions at the doses of 100, 200, and 400 mg/ $\mathrm{kg}$ by the oral route. The urine volume, urine $\mathrm{pH}$, urine, and serum electrolytes were determined and compared with the standard and normal control groups. Results. The crude hydromethanolic extract, ethyl acetate, and chloroform fractions induced significant diuresis at a dose of $400 \mathrm{mg} / \mathrm{kg}(P<0.001)$ compared to the aqueous fraction. The hydromethanolic extract at $200 \mathrm{mg} / \mathrm{kg}$ and $400 \mathrm{mg} / \mathrm{kg}$ also caused noticeable diuresis $(P<0.001)$ compared to the standard, furosemide. Rats treated with hydromethanolic extract, ethyl acetate, and chloroform fractions showed delayed onset and prolonged diuresis in a dose-dependent fashion compared to the aqueous fraction $(P<0.05)$. The hydromethanolic extract and solvent fractions produced the highest saliuretic and natriuretic index compared to the standard, furosemide. The crude hydromethanolic extract also failed to produce any sign of toxicity up to $2000 \mathrm{mg} / \mathrm{kg}$. Conclusion. From this study, the hydromethanolic extract and ethyl acetate fraction of the root bark of C. myricoides produced a prominent diuretic effect in rats.
\end{abstract}

\section{Introduction}

Substances that elevate the rate of urine flow and salt loss are known as diuretics $[1,2]$. The net excretory effect of diuretic agents causes changes in urine flow, $\mathrm{pH}$, and ionic compositions of urine and blood [3]. Diuretic agents are important to promote a net loss of excessive accumulated body fluids, salts, toxemias, and other accumulated metabolic products including urea [4]. However, the currently available diuretic agents are associated with numerous side effects and diuretic resistance in some patients. For instance, the recent global cohort studies indicated that the prevalence of diuretic resistance was estimated to be $20-35 \%$ in heart failure cases $[5,6]$.

Therefore, there is a need to look for alternative diuretics with a novel mode of action, better efficacy, and tolerable side effects profile. Medicinal plants are considered as a vital source for the development of potential therapeutic effective 
drugs. C. myricoides (Lamiaceae) is locally called "Surbetri or Shiwha" in Tigrigna [7, 8]. Most of the plant species under this genus are a rich source of biologically active secondary metabolites such as terpenes, tannins, steroids, phenolic acids, glycosides, flavonoids, and alkaloids [8]. A number of species from this genus were previously reported to have several pharmacological activities including diuretics action and antihypertensive $[9,10]$.

The methanolic leaf and root extracts of C. myricoides have been examined for different pharmacological activities. For instance, the leaf part was examined for the antiplasmodial [11], antifungal, and antibacterial activities [12]. Notable antimicrobial activity against all tested pathogens was also reported from the root part of this plant [13]. Besides, phytochemical screening of the methanolic root extract of $C$. myricoides showed the presence of flavonoids, terpenoids, phenols, glycosides, tannins, and saponins [14].

Based on the information obtained from the local community (Adwa, Tigray) and supported by ethnobotanical reports, the root bark of $C$. myricoides is claimed to promote diuresis. The powdered root bark of C. myricoides with the addition of water is orally administered for swelling in the body, urination problem, and/or urinary retention $[8,15]$.

The widespread use of the medicinal plant by local people entails the necessity of testing of their efficacy and safety profile [16]. Therefore, this study aimed to investigate the effect of both the hydromethanolic extract and different solvent fractions of the root bark of C. myricoides on the urine output, urine $\mathrm{pH}$, and both urine and serum electrolytes of rats.

\section{Materials and Methods}

2.1. Drugs, Chemicals, and Reagents. Ketamine hydrochloride (Neon Laboratories Limited, India), furosemide (Changzhou Yabang Pharmaceutical, China), absolute methanol (Alpha Chemika, India), chloroform (Nice Chemicals, India), ethyl acetate (Fine Chem, India), tween 80 (Atlas Chemicals, India), and normal saline (Addis Pharmaceutical Factory, Ethiopia). All the other chemicals used were also laboratory and/or analytical grade.

2.2. Experimental Plant. The fresh root of C. myricoides was collected in December 2018 and identified, and specimens (voucher number of ETH/05/2011/2019) were deposited at the National Herbarium, Addis Ababa University. The roots were thoroughly washed with tap water; root bark was separated and cut to smaller sizes, dried under shade for two weeks, and coarsely powdered using a mechanical grinder.

\subsection{Preparation of Crude Extract and Solvent Fractions.} After drying, $1500 \mathrm{~g}$ of the coarsely powdered root bark of C. myricoides was macerated in 7.5 liters of $80 \%$ of methanol for $72 \mathrm{hr}$ with occasional agitation using the orbital shaker. The macerate was separated using a triple-layered muslin cloth followed by Whatman No. 1 filter paper. The marc was resoaked twice to obtain sufficient yield following the same procedure. The combined filtrate was concentrated in the oven dryer at $40^{\circ} \mathrm{C}$.

Then, $130 \mathrm{~g}$ of the hydromethanolic extract (HME) was allowed to suspend in $200 \mathrm{~mL}$ of distilled water. A $200 \mathrm{~mL}$ of chloroform was added into aqueous suspension and vigorously shaken in a separatory funnel and kept until a clear layer appeared. The bottom layer of the chloroform fraction was separated into a glass beaker. The aqueous residue was reshaken twice with the addition of the same volume of fresh chloroform following a similar protocol. The remaining aqueous residue was then mixed and shaken thrice with $200 \mathrm{~mL}$ of ethyl acetate following the above procedure (but the upper layer was ethyl acetate fraction). At the end, all the fractions were concentrated in the oven dryer at $40^{\circ} \mathrm{C}$.

2.4. Experimental Animals. Swiss albino mice and Sprague-Dawley rats were obtained from the animal breeding house of the Department of Pharmacology and Toxicology, Mekelle University. Before starting the experiments, all the animals were housed individually in the standard plastic cage inside the experimental laboratory room (natural light/ dark cycles) with free access to standard food and tap water. The study clearance was obtained from the Health Research Ethics Review Committee of the College of Health Sciences, Mekelle University, with protocol number 1538/2018.

2.5. Acute Oral Toxicity Study. The study was carried out by a limit test of the Organization for Economic Cooperation and Development Guideline No. 425 [17]. Five none pregnant female mice weighed between $25 \mathrm{~g}$ and $30 \mathrm{~g}$ and aged 8-12 weeks were used for this study. All mice fasted for food, but not for water, $4 \mathrm{hr}$ before dosing and for $2 \mathrm{hr}$ after administration of the extract. The dose was calculated according to the bodyweight of the fasted mice. Initially, one mouse was treated with a single dose of the extract, $2000 \mathrm{mg} /$ $\mathrm{kg}$. After a day, since the mouse survived, continued to administer a single dose $(2000 \mathrm{mg} / \mathrm{kg})$ for 4 mice. After administration of the extract, the mice were carefully observed for short-term toxicity profile up to $24 \mathrm{hr}$ and up to 14 days for the mortality profile.

2.6. Grouping and Dosing. Either sex of Sprague-Dawley rats having a weight range of 200-250 $\mathrm{g}$ and age of 12-16 weeks were distributed into fifteen groups randomly ( $n=6$ /group). The groups were randomly assigned as two normal control groups, one standard group and the rest (group IV up to XV) as $C$. myricoides treatment groups. Before commencing the experimentation, each rat was placed daily for $3 \mathrm{hr}$ for a total of 3 days in the metabolic cage, for acclimatization [18]. The hydromethanolic extract and its AF were freshly prepared in distilled water, while the EAF and CF were dissolved in $2 \%$ tween 80 on the day of the experiment and administered orally. Accordingly, the first normal control group was treated with distilled water, and the second normal control group was treated with $2 \%$ tween 80 . The standard group was treated with furosemide $10 \mathrm{mg} / \mathrm{kg}$ [19], while groups IV-XV were treated with the three different test doses $(100,200$, and 
$400 \mathrm{mg} / \mathrm{kg}$ ) of the root bark of C. myricoides HME and its solvent fractions.

2.7. Diuretic Activity. The screening of diuretic activity was performed using the model described by Lipschitz [20] and $\mathrm{Kau}$ [21]. The overnight fasted rats for food but not for water were hydrated using a single oral dose of normal saline $25 \mathrm{~mL} / \mathrm{kg}$ [22]. At the beginning of the treatment, the fasted but hydrated rat's urinary bladder was emptied by gently compressing at the pelvic area and using the pulldown of their tails [23]. Then, the rats were administered the test doses as described in the section of grouping and dosing. Immediately after administration, the rats were placed individually in the metabolic cage. The excreted urine volume was collected and measured at the end of $1 \mathrm{sthr}, 2 \mathrm{nd} \mathrm{hr}$, 4th hr, 6th hr, and at the last 24th hr intervals after dosing [24]. Urine $\mathrm{pH}$ was measured from a fresh urine sample of each rat using a digital $\mathrm{pH}$ meter [23]. The collected urine was stored in a refrigerator $\left(-80^{\circ} \mathrm{C}\right)$ for further urine analysis.

The percentage of urine excretion (formula (1)), diuretic action (formula (2)), and diuretic index (formula (3)) was calculated for all groups using the mean urine output at 6 th and $24 \mathrm{th} \mathrm{hr}$. The obtained diuretic index was considered good if the resulted values were $>1.5$, moderate if the resulted values depict between 1.00 and 1.5, least if the resulted values range between 0.72 and 0.99 , and nil if the resulted values $<0.72[19,23]$.

Urinary excretion $=\frac{\text { Total urinary output }}{\text { Total volume of liquid administered }} * 100$,

Diuretic action $=\frac{\text { Urinary excretion of the test group }}{\text { Urinary excretion of the control group }}$,

Diuretic index $=\frac{\text { Diuretic action of the test group }}{\text { Diuretic action of the standard group }}$.

2.8. Biochemical Analysis. At the end of the experiment, all rats were anesthetized using ketamine hydrochloride $(75 \mathrm{mg} / \mathrm{kg}$ IP), and blood was collected from each rat through the retroorbital sinus [25]. The serum was separated by centrifugation at 2500 rotation per minute for 10 minutes for further serum electrolyte analysis. The urinary (from the $24 \mathrm{hr}$ urine) and serum electrolyte contents including $\mathrm{Na}^{+}$, $\mathrm{K}^{+}$, and $\mathrm{Cl}^{-}$were analyzed using Cobas ${ }^{\circledast} 6000$ analyzer series (Roche, Germany).

Using the data obtained from urine electrolytes analysis, saliuretic index was calculated for an individual $\mathrm{Na}^{+}, \mathrm{K}^{+}$, and $\mathrm{Cl}^{-}$as a ratio of their concentrations in the treated groups compared to the normal control group (formula (4)) [26].
Saliuretic index $=\frac{\text { Urinary } \mathrm{Na}^{+}, \mathrm{K}^{+}, \mathrm{Cl}^{-} \text {level in the test group }}{\text { Urinary } \mathrm{Na}^{+}, \mathrm{K}^{+}, \mathrm{Cl}^{-} \text {level in the control group }}$.

Using the data obtained from urine electrolytes analysis in the same group, natriuretic index or aldosterone secretion index $\left(\mathrm{Na}^{+}\right.$ratio to $\mathrm{K}^{+}$) (formula (5)) and carbonic anhydrase inhibition (CAI) index $\left(\mathrm{Cl}^{-}\right.$ratio to sum of $\left.\mathrm{Na}^{+}+\mathrm{K}^{+}\right)$ (formula (6)) were calculated [26-28].

Natriuretic index $=\frac{\text { Urinary } \mathrm{Na}^{+} \text {level in the same test group }}{\text { Urinary } \mathrm{K}^{+} \text {level in the same test group }}$,

CAI index $=\frac{\text { Urinary } \mathrm{Cl}^{-} \text {level in the same test group }}{\text { Sum of urinary } \mathrm{Na}^{+}+\mathrm{K}^{+} \text {level in the same test group }}$.

If the obtained $\mathrm{Na}^{+} / \mathrm{K}^{+}$ratio $>1$, it indicates a satisfactory natriuretic index [29], and if $>2$, it indicates favorable $\mathrm{Na}^{+}$ urinary excretion without excessive urinary $\mathrm{K}^{+}$loss, but if $>10$, it indicates a favorable $\mathrm{K}^{+}$sparing effect [30]. If the calculated value of the $\mathrm{Cl}^{-} / \mathrm{Na}^{+}+\mathrm{K}^{+}$ratio is between 0.8 and 1.00 , it excludes CAI activities, but if below 0.8 , it is considered to have a strong CAI index [31].

2.9. Data Analysis. The data in this study were analyzed using a statistical package for social science, version 20 . The results of the study were expressed as mean \pm standard error of the mean (SEM). Statistical significant differences were determined by one-way ANOVA followed by the post hoc Tukey test to compare urine volume, urine, and serum electrolyte concentration among the controls, standards, HME, and solvent fractions treated groups. $P$ value $<0.05$ was considered statistically significant.

\section{Results}

3.1. Percentage Yield of the Plant Extract. The percentage yield of HME was $35.62 \%$, and among its solvent fractions, the AF had the highest percentage yield, $92.88 \%$, while the $\mathrm{CF}, 6.33 \%$, and the EAF, $0.75 \%$, showed lower extraction yields.

3.2. Acute Oral Toxicity Study. The crude extract (HME) of the root bark of C. myricoides (at a dose of $2000 \mathrm{mg} / \mathrm{kg}$ ) did not produce any physically visible sign of toxicity, up to 14 days of follow-up.

3.3. Diuretic Activity: Effect on Urine Output. The effect of HME on urine output is presented in Figure 1. All test doses of HME caused continual urine output until the 24th hr compared to the normal control group $(P<0.001)$. Both $200 \mathrm{mg} / \mathrm{kg}(P<0.01)$ and $400 \mathrm{mg} / \mathrm{kg}(P<0.001)$ test doses of HME produced better urine output starting from the $6 \mathrm{th} \mathrm{hr}$ compared to the normal control group. The HME at $400 \mathrm{mg} /$ $\mathrm{kg}$ also showed better diuresis starting from the $6 \mathrm{th} \mathrm{hr}$ and continued until the 24th hr compared to furosemide 


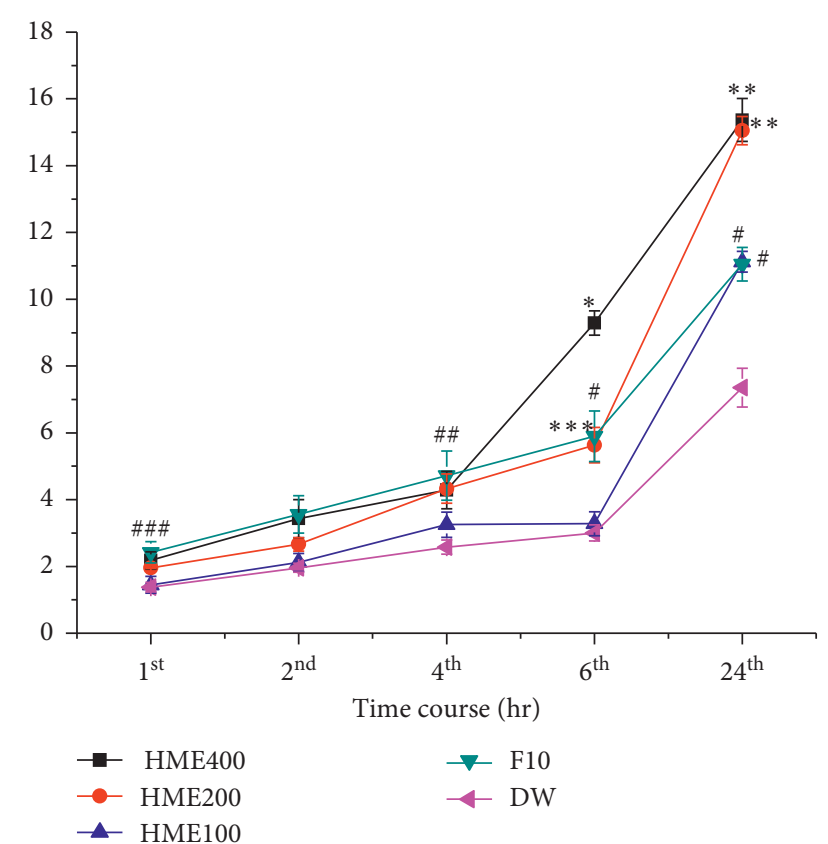

FIgURE 1: The effect of the hydromethanolic extract of the root bark of Clerodendrum myricoides on $24 \mathrm{hr}$ urine volume in rats. Compared to HME: hydromethanolic extract $\left({ }^{\mathrm{a}} 400,{ }^{\mathrm{b}} 200\right.$, ${ }^{\mathrm{c}} 100 \mathrm{mg} / \mathrm{kg}$ ); ${ }^{\mathrm{d}}$ compared to F10: furosemide $10 \mathrm{mg} / \mathrm{kg}$; ${ }^{\mathrm{e}}$ compared to DW: distilled water. ${ }^{1} P<0.05 ;{ }^{2} P<0.01 ;{ }^{3} P<0.001$. Key: ${ }^{*}$ (b3, c3, d3, e3), ${ }^{* *}(\mathrm{c} 3, \mathrm{~d} 3, \mathrm{e} 3)$, and ${ }^{* * *}(\mathrm{c} 1, \mathrm{e} 2)$ and ${ }^{\#}(\mathrm{e} 3),{ }^{\# \#}(\mathrm{e} 2)$, and $\# \#$ (e1).

(F10 mg/kg) treated rats $(P<0.001)$. The $200 \mathrm{mg} / \mathrm{kg}$ dose also caused an increment of urine output at the last $24 \mathrm{th} \mathrm{hr}$ compared to $\mathrm{F} 10 \mathrm{mg} / \mathrm{kg}$ treated rats $(P<0.001)$.

Unlike the HME, all the test doses of AF failed to show a significant increment of urine output (Table 1). The EAF exhibited increment of urine output at $400 \mathrm{mg} / \mathrm{kg}$ starting from the 6 th hr compared to the normal control group $(P<0.05)$. It also $(400 \mathrm{mg} / \mathrm{kg})$ displayed a noticeable and continuous increment of urine output until the 24 th hr compared to the normal control group $(P<0.001)$. In this fraction, both the $200 \mathrm{mg} / \mathrm{kg}$ and $100 \mathrm{mg} / \mathrm{kg}$ also caused a significant increment of urine output compared to the normal control at the last 24th hr. The CF of the HME produced a significant increment of urine output in a dosedependent manner compared to the normal control group at the 24th hr.

Moreover, the highest and lowest percentages of urinary excretion, diuretic action, and diuretic index were observed at $400 \mathrm{mg} / \mathrm{kg}$ and $100 \mathrm{mg} / \mathrm{kg}$ doses of the HME, respectively (Figure 2). However, at $24 \mathrm{th} \mathrm{hr}$, the highest percentage of urinary excretion, diuretic action, and diuretic index at a dose of $200 \mathrm{mg} / \mathrm{kg}$ of the HME with values of $215 \%, 2.04$, and 1.13, respectively, was observed.

Furthermore, the highest percentage of urinary excretion, diuretic action, and diuretic index was also observed at the largest test dose of EAF and CF at both 6 th hr and 24th hr (Table 2). Unlike the HME, EAF, and CF, all the test doses of the AF appeared to have "nil" $(<0.72)$ diuretic index.
3.4. Urine $p H$. As displayed in Figure 3, both the collected urine from the groups treated with HME and F10 mg/kg treated rats were found to have slightly lower urine $\mathrm{pH}$ while the test doses of the AF, EAF, and CF of the HME have caused slightly alkaline urine $\mathrm{pH}$.

3.5. Electrolyte Content of the Urine. The effect of HME and solvent fractions of the root bark of C. myricoides on urinary electrolyte excretion is shown in Table 3. The HME at $200 \mathrm{mg} / \mathrm{kg}$ and $\mathrm{F} 10 \mathrm{mg} / \mathrm{kg}$ treated rats has produced the highest urinary $\mathrm{K}^{+}$excretion $(P<0.01)$. Besides, the $200 \mathrm{mg} /$ $\mathrm{kg}$ of the HME showed an increment of urinary $\mathrm{Cl}^{-}$excretion compared to the normal control group and F10 mg/ $\mathrm{kg}$ treated rats $(P<0.05)$. The least urinary $\mathrm{Na}^{+}, \mathrm{K}^{+}$, and $\mathrm{Cl}^{-}$ excretion was observed at $400 \mathrm{mg} / \mathrm{kg}$ of the HME of the plant. Compared to the test doses of the HME, the $200 \mathrm{mg} / \mathrm{kg}$ showed comparable saliuretic index with the $\mathrm{F} 10 \mathrm{mg} / \mathrm{kg}$ treated rats. The least saliuretic index and the highest natriuretic index values were observed at $400 \mathrm{mg} / \mathrm{kg}$ compared to the F10 mg/kg treated rats. All the test doses of HME have produced $<0.8$ CAI index.

The AF at $400 \mathrm{mg} / \mathrm{kg}$ caused increment of $\mathrm{K}^{+}(P<0.01)$ and $\mathrm{Cl}^{-}(P<0.001)$ urinary excretion compared to the normal control group. The EAF at $200 \mathrm{mg} / \mathrm{kg}(P<0.01)$ and $400 \mathrm{mg} / \mathrm{kg}(P<0.05)$ showed substantial urinary $\mathrm{Na}^{+}$excretion compared to the normal control group and F10 mg/ $\mathrm{kg}$ treated rats. The CF at $400 \mathrm{mg} / \mathrm{kg}$ caused increment of urinary $\mathrm{Na}^{+}, \mathrm{K}^{+}$, and $\mathrm{Cl}^{-}$excretion compared to the normal control group $(P<0.05),(P<0.01)$, and $(P<0.001)$, respectively. Furthermore, the rats treated with larger test doses of AF, EAF, and CF were also found to have a higher saliuretic index than $\mathrm{F} 10 \mathrm{mg} / \mathrm{kg}$ treated rats. In addition, rats treated with AF (at 100 and $200 \mathrm{mg} / \mathrm{kg}$ ), EAF (at 200 and $400 \mathrm{mg} / \mathrm{kg}$ ), and CF (at $100 \mathrm{mg} / \mathrm{kg}$ ) showed higher natriuretic index $(>1)$. The least CAI index was observed at both $200 \mathrm{mg} / \mathrm{kg}$ and $400 \mathrm{mg} / \mathrm{kg}$ doses of EAF and that of F10 mg/ $\mathrm{kg}$ treated rats.

3.6. Electrolyte Content in the Serum. The effect of HME and solvent fractions of the root bark of C. myricoides on serum electrolyte levels is shown in Table 4 . The rats treated with $400 \mathrm{mg} / \mathrm{kg}$ of HME appeared to have higher $\mathrm{K}^{+}$serum level compared to that of $\mathrm{F} 10 \mathrm{mg} / \mathrm{kg}$ treated rats $(P<0.01)$. Higher serum $\mathrm{Na}^{+}(P<0.01)$ and $\mathrm{Cl}^{-}(P<0.05)$ levels were observed at $100 \mathrm{mg} / \mathrm{kg}$ of the HME compared to the HME at $400 \mathrm{mg} / \mathrm{kg}$. Substantial increment of the serum $\mathrm{Na}^{+}$level was observed at $100 \mathrm{mg} / \mathrm{kg}(P<0.01)$ and $200 \mathrm{mg} / \mathrm{kg}(P<0.05)$ of AF compared to the normal control group. All test doses of AF, however, showed decrement of the serum $\mathrm{K}^{+}$level compared to the normal control group $(P<0.001)$.

The rats treated with the $100 \mathrm{mg} / \mathrm{kg}(P<0.001)$ of EAF were found to have higher serum $\mathrm{Na}^{+}$level compared to the normal control. When compared all the test doses of EAF, it was observed that the $200 \mathrm{mg} / \mathrm{kg}$ caused higher serum $\mathrm{K}^{+}$ level compared to the $400 \mathrm{mg} / \mathrm{kg}(P<0.01)$. The $\mathrm{CF}$ at $200 \mathrm{mg} / \mathrm{kg}$ and $400 \mathrm{mg} / \mathrm{kg}$ treated rats also showed a substantial serum $\mathrm{Na}^{+}$level increment compared to the normal control and $\mathrm{F} 10 \mathrm{mg} / \mathrm{kg}$ treated rats $(P<0.01)$. The minimal 
TABLE 1: The effect of solvent fractions of the root bark of Clerodendrum myricoides on $24 \mathrm{hr}$ urine volume in rats.

\begin{tabular}{|c|c|c|c|c|c|}
\hline \multirow{2}{*}{ Dose (mg/kg) } & \multicolumn{5}{|c|}{${ }^{*}$ Urine volume $(\mathrm{mL})$} \\
\hline & 1 sthr & 2nd hr & 4th hr & 6th hr & 24th hr \\
\hline AF400 & $0.33 \pm 0.21^{\mathrm{c} 2, \mathrm{~d} 3, \mathrm{e} 1}$ & $0.75 \pm 0.47^{\mathrm{d} 3}$ & $1.83 \pm 0.38^{\mathrm{d} 3}$ & $2.75 \pm 0.35^{\mathrm{d} 3}$ & $8.33 \pm 0.83^{\mathrm{d} 1}$ \\
\hline AF200 & $0.33 \pm 0.21^{\mathrm{c} 2, \mathrm{~d} 3, \mathrm{e} 1}$ & $1.66 \pm 0.55^{\mathrm{d} 1}$ & $2.33 \pm 0.16^{\mathrm{d} 2}$ & $3.66 \pm 0.27^{\mathrm{d} 2}$ & $8.50 \pm 0.21^{\mathrm{d} 1}$ \\
\hline AF100 & $1.50 \pm 0.18^{\mathrm{d} l}$ & $2.33 \pm 0.10$ & $2.83 \pm 0.05^{\mathrm{d} 1}$ & $2.83 \pm 0.52^{\mathrm{d} 3}$ & $7.83 \pm 0.36^{\mathrm{d} 2}$ \\
\hline EAF400 & $1.05 \pm 0.46$ & $2.67 \pm 0.42$ & $4.33 \pm 0.40$ & $5.70 \pm 0.31^{\mathrm{e} 1}$ & $11.54 \pm 0.50^{\mathrm{c} 1, \mathrm{e} 3}$ \\
\hline EAF200 & $1.00 \pm 0.44$ & $2.15 \pm 0.45$ & $3.45 \pm 0.31$ & $4.45 \pm 0.27$ & $9.95 \pm 0.34^{\mathrm{e} 3}$ \\
\hline EAF100 & $1.50 \pm 0.18$ & $3.61 \pm 0.35$ & $3.74 \pm 0.33$ & $4.62 \pm 0.50$ & $9.09 \pm 0.62^{\mathrm{e} 1}$ \\
\hline CF400 & $1.58 \pm 0.32$ & $2.95 \pm 0.20$ & $3.91 \pm 0.15$ & $5.25 \pm 0.21^{\mathrm{e} 2}$ & $10.86 \pm 0.44^{\mathrm{b} 1, \mathrm{e} 3}$ \\
\hline CF200 & $2.25 \pm 0.51$ & $3.12 \pm 0.17$ & $2.25 \pm 0.50^{\mathrm{d} 2}$ & $2.50 \pm 0.54^{\mathrm{d} 3}$ & $10.50 \pm 0.78^{\mathrm{b} 1, \mathrm{e} 3}$ \\
\hline CF100 & $1.50 \pm 0.18$ & $2.12 \pm 0.12^{\mathrm{d} l}$ & $2.91 \pm 0.08^{\mathrm{d} 1}$ & $3.97 \pm 0.20^{\mathrm{d} l}$ & $8.12 \pm 0.48^{\mathrm{d} 2}$ \\
\hline F10 & $2.42 \pm 0.32^{\mathrm{e} 1}$ & $3.56 \pm 0.55$ & $4.72 \pm 0.74^{\mathrm{e} 2}$ & $5.9 \pm 0.76^{\mathrm{e} 3}$ & $11.05 \pm 0.50^{\mathrm{e} 3 \mathrm{c}}$ \\
\hline DW & $1.38 \pm 0.14$ & $1.96 \pm 0.13$ & $2.58 \pm 0.21$ & $3 \pm 0.24$ & $7.35 \pm 0.58$ \\
\hline $2 \% \mathrm{TDW}$ & $1.37 \pm 0.32$ & $2.29 \pm 0.40$ & $2.83 \pm 0.30$ & $3.32 \pm 0.24$ & $6.66 \pm 0.42$ \\
\hline
\end{tabular}

${ }^{*}$ Results are expressed as mean $\pm \operatorname{SEM}(n=6)$. Compared to AF: aqueous fraction $\left({ }^{\mathrm{a}} 400,{ }^{\mathrm{b}} 200,{ }^{\mathrm{c}} 100 \mathrm{mg} / \mathrm{kg}\right) ;{ }^{\mathrm{d}}$ compared to F10: furosemide $10 \mathrm{mg} / \mathrm{kg}$; ${ }^{\mathrm{e}}$ compared to DW: distilled water; compared to EAF: ethyl acetate fraction $\left({ }^{\mathrm{a}} 400,{ }^{\mathrm{b}} 200,{ }^{\mathrm{c}} 100 \mathrm{mg} / \mathrm{kg}\right)$; compared to CF: chloroform fraction $\left({ }^{\mathrm{a}} 400\right.$, ${ }^{\mathrm{b}} 200$, ${ }^{\mathrm{c}} 100 \mathrm{mg} / \mathrm{kg}$ ); ${ }^{\mathrm{d}}$ compared to F10: furosemide $10 \mathrm{mg} / \mathrm{kg}$; ${ }^{\mathrm{e}}$ compared to $2 \%$ TDW: $2 \%$ Tween $80 .{ }^{1} P<0.05 ;{ }^{2} P<0.01 ;{ }^{3} P<0.001$.

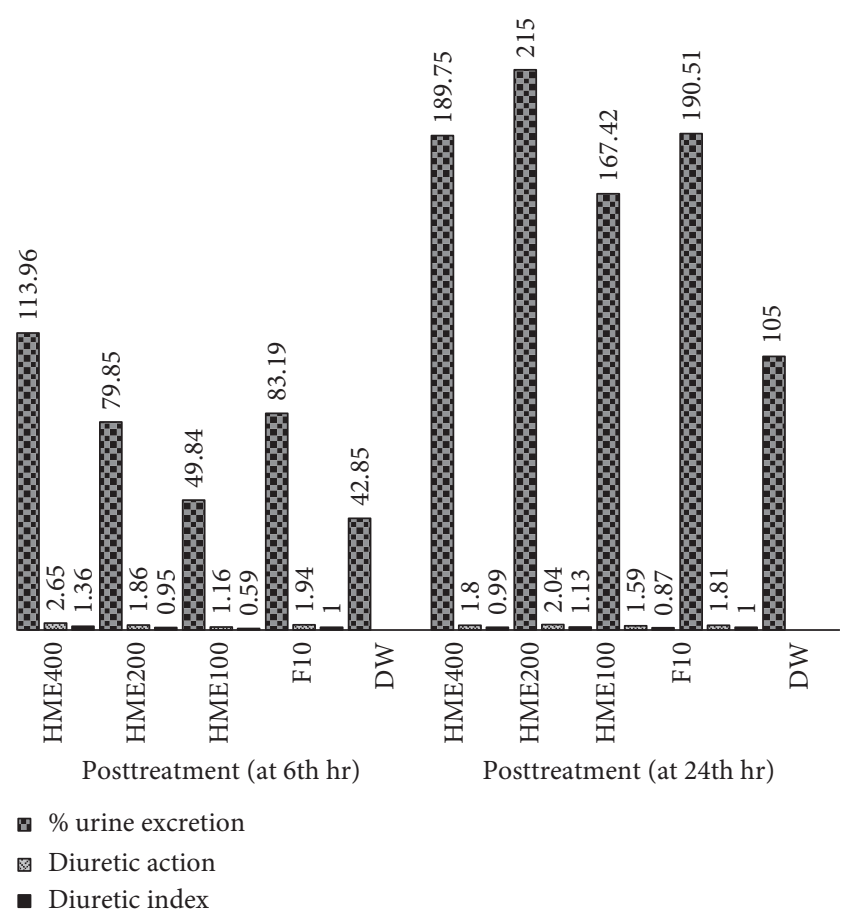

FIgURE 2: Diuretic index of the hydromethanolic extract of the root bark of Clerodendrum myricoides at 6th hr and 24th hr. HME, hydromethanolic extract; F10, furosemide $10 \mathrm{mg} / \mathrm{kg}$; DW, distilled water.

serum $\mathrm{K}^{+}$level was observed at both doses of $100 \mathrm{mg} / \mathrm{kg}$ and $200 \mathrm{mg} / \mathrm{kg}$ compared to the normal control $(P<0.001)$.

\section{Discussion}

Diuretic agents are substances when introduced into a biological system, and they are increasing the net loss of urine and salts [30]. Urine and serum electrolyte, urine volume, and urine $\mathrm{pH}$ were measured as a parameter to evaluate the diuretic activity of the root bark of C. myricoides in rats used in this study.
The rats treated with three test doses of HME, EAF, and $\mathrm{CF}$, especially at maximum test doses, showed a significant increment of urine output, starting from the 6th hr and continued till the 24th hr compared to the normal control. However, among the fractions, AF failed to reveal a significant increment of urine output. This could be attributed due to the existence of higher concentration of the diuretic active ingredient(s) in the HME and variation in type, quality, and quantity of active constituent(s) presented in these fractions $[32,33]$.

The delayed diuresis onset with the HME and its EAF and $\mathrm{CF}$ may be ascribed due to the slow absorption properties of the responsible active ingredient(s). The long diuresis duration of action with the HME and its EAF and CF throughout the study period (until the 24th hr) may be attributed due to the slow clearance properties of the responsible ingredient(s) [27, 28, 34].

The extracts showed different degrees of the percentage of urinary excretion, diuretic action, and diuretic index at both $6 \mathrm{th} \mathrm{hr}$ and 24th hr. The higher percentage of urinary excretion, diuretic action, and the diuretic index was noticed from the HME followed by EAF and CF, while the lowest was noticed in the AF. The percentage of urinary excretion, diuretic action, and diuretic index of the HME, EAF, and CF showed to rise in a dose-dependent fashion.

Based on the estimated diuretic index, the diuretic potential of the HME and solvent fractions was ranked as "nil," "least," "moderate," and "good," if the calculated values were $<0.72,0.72-0.99,1.00-1.5$, and $>1.5$, respectively $[23,35]$. Consequently, the HME (at 400 and $200 \mathrm{mg} / \mathrm{kg}$ ) and EAF at $400 \mathrm{mg} / \mathrm{kg}$ showed a "moderate" diuretic index. The CF at $400 \mathrm{mg} / \mathrm{kg}$ has a "least" diuretic index, while the AF elicited a "nil" diuretic index. Therefore, this clearly showed that the ingredient(s) presented in the HME and EAF might be considered as the responsible constituent for the observed superior diuretic index.

The HME caused a significant increment in urine $\mathrm{K}^{+}$and $\mathrm{Cl}^{-}$excretion with lesser $\mathrm{Na}^{+}$and $\mathrm{Cl}^{-}$in serum, without serum $\mathrm{K}^{+}$level alteration as compared to that of $\mathrm{F} 10 \mathrm{mg} / \mathrm{kg}$ treated rats. The HME, especially at $200 \mathrm{mg} / \mathrm{kg}$, was able to 
TABle 2: Diuretic index of solvent fractions of the root bark of Clerodendrum myricoides at 6th hr and 24th hr.

\begin{tabular}{|c|c|c|c|c|c|c|}
\hline \multirow{2}{*}{ Dose $(\mathrm{mg} / \mathrm{kg})$} & \multicolumn{3}{|c|}{ Posttreatment (at 6th hr) } & \multicolumn{3}{|c|}{ Posttreatment (at 24th hr) } \\
\hline & Urinary excretion & Diuretic action & Diuretic index & Urinary excretion & Diuretic action & Diuretic index \\
\hline AF400 & 37.11 & 0.86 & 0.44 & 112.56 & 1.07 & 0.59 \\
\hline AF200 & 58.74 & 1.37 & 0.70 & 137.09 & 1.30 & 0.71 \\
\hline AF100 & 47.10 & 1.10 & 0.56 & 130.5 & 1.24 & 0.68 \\
\hline EAF400 & 95 & 1.59 & 0.94 & 192.33 & 1.73 & 1.01 \\
\hline EAF200 & 74.16 & 1.24 & 0.73 & 165.83 & 1.49 & 0.87 \\
\hline EAF100 & 76.87 & 1.29 & 0.76 & 151.5 & 1.36 & 0.79 \\
\hline CF400 & 84.67 & 1.42 & 0.84 & 175.16 & 1.57 & 0.91 \\
\hline CF200 & 40.91 & 0.68 & 0.40 & 172.13 & 1.55 & 0.90 \\
\hline CF100 & 63.16 & 1.06 & 0.63 & 135.33 & 1.21 & 0.70 \\
\hline F10 & 100.16 & 1.68 & 1 & 190.51 & 1.71 & 1 \\
\hline DW & 42.85 & - & - & 105 & - & - \\
\hline $2 \% \mathrm{TDW}$ & 59.46 & - & - & 111 & - & - \\
\hline
\end{tabular}

$\mathrm{AF}$, aqueous fraction; F10, furosemide $10 \mathrm{mg} / \mathrm{kg}$; DW, distilled water; EAF, ethyl acetate fraction; $\mathrm{CF}$, chloroform fraction; and 2\%TDW, $2 \%$ Tween 80 in distilled water.

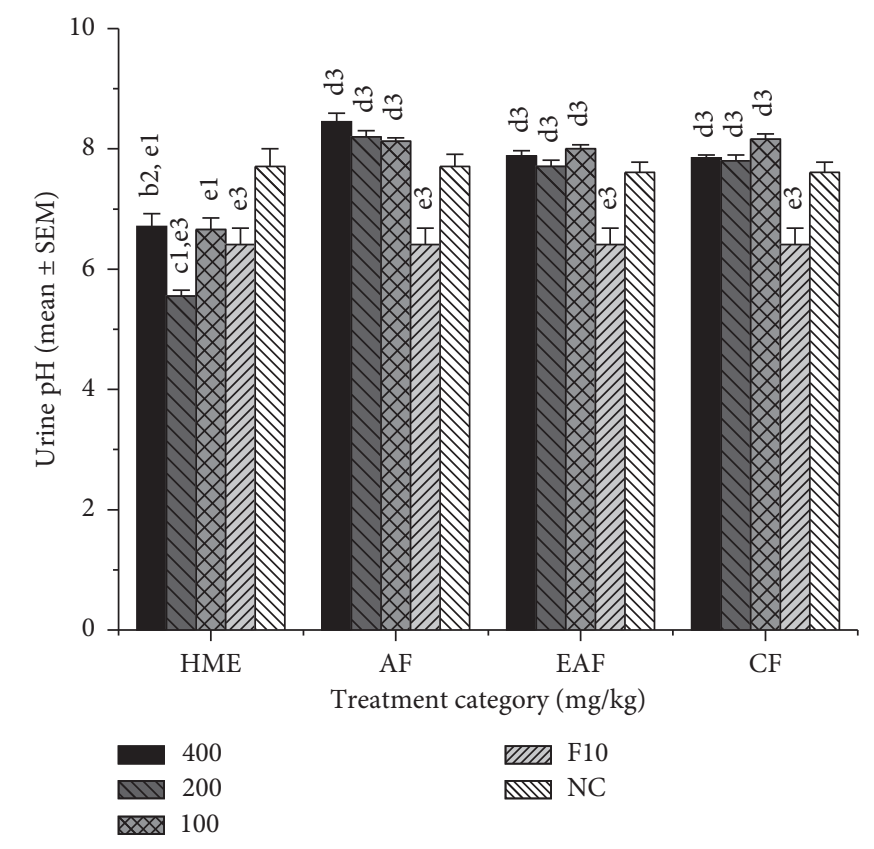

FIgURE 3: Urine $\mathrm{pH}$ of rats $(n=6)$ treated with the hydromethanolic extract and solvent fractions of the root bark of Clerodendrum myricoides. HME, hydromethanolic extract ( ${ }^{\mathrm{a}} 400$, $\left.{ }^{\mathrm{b}} 200,{ }^{\mathrm{c}} 100 \mathrm{mg} / \mathrm{kg}\right) ; \mathrm{AF}$, aqueous fraction $\left({ }^{\mathrm{a}} 400,{ }^{\mathrm{b}} 200,{ }^{\mathrm{c}} 100 \mathrm{mg} / \mathrm{kg}\right)$; EAF, ethyl acetate fraction $\left({ }^{\mathrm{a}} 400,{ }^{\mathrm{b}} 200,{ }^{\mathrm{c}} 100 \mathrm{mg} / \mathrm{kg}\right)$; CF, chloroform fraction ( ${ }^{\mathrm{a}} 400,{ }^{\mathrm{b}} 200,{ }^{\mathrm{c}} 100 \mathrm{mg} / \mathrm{kg}$ ); ${ }^{\mathrm{d}} \mathrm{F} 10$, furosemide $10 \mathrm{mg} / \mathrm{kg}$; ${ }^{\mathrm{e}} \mathrm{NC}$, normal control (either distilled water compared to HME and AF or $2 \%$ Tween 80 compared to EAF and CF). ${ }^{1} P<0.05 ;{ }^{2} P<0.01$; ${ }^{3} P<0.001$.

elicit saliuretic index as closer to $\mathrm{F} 10 \mathrm{mg} / \mathrm{kg}$ treated rats. This could be related to the presence of higher $\mathrm{K}^{+}$content in the plant extract and might have advantageous during hypokalemic conditions [19].

Loop diuretics enhance urinary outflow and excretion of $\mathrm{Na}^{+}, \mathrm{K}^{+}$, and $\mathrm{Cl}^{-}$[36]. When loop diuretics inhibit $\mathrm{Na}^{+} / \mathrm{K}^{+} /$ $2 \mathrm{Cl}^{-}$cotransporter at the thick ascending limb of the loop of Henle, it leads to increased $\mathrm{Na}^{+}$load to the distal convoluted tubule, which indirectly causes urine acidification [36].
Hence, the HME caused significant urine $\mathrm{K}^{+}$and $\mathrm{Cl}^{-}$excretion (at $200 \mathrm{mg} / \mathrm{kg}$ ), satisfactory natriuresis index (at $400 \mathrm{mg} / \mathrm{kg}$ ), and significant acidic urine at all test doses. Therefore, it can be suggested that HME of the plant might have loop diuretic like the mechanism of action.

Besides, both the EAF and CF caused increment of urinary $\mathrm{Na}^{+}, \mathrm{K}^{+}$, and $\mathrm{Cl}^{-}$excretion with significant alkalization of urine. As a result, the diuretic activity of the EAF and CF may be different from loop-like diuretics because loop diuretics cause marked natriuresis and urine acidification [16]. It is reasonable to suggest that the constituent(s) present in the root bark of $C$. myricoides seems to have different diuretic mechanisms of action.

The $\mathrm{Na}^{+} / \mathrm{K}^{+}$ratio if $>1,2$, and 10 indicates satisfactory natriuresis, a favorable natriuresis, and favorable $\mathrm{K}^{+}$sparing activity, respectively $[29,30]$. Accordingly, the HME and EAF showed a satisfactory natriuretic index. However, in the present study, none of the test doses of HME and solvent fractions showed a favorable natriuretic index and $\mathrm{K}^{+}$ sparing activity. These findings are concurred with other previous diuretic plant studies (similar in the family), which have shown satisfactory natriuretic index and no $\mathrm{K}^{+}$sparing activity [37].

The $\mathrm{Cl}^{-} / \mathrm{Na}^{+}+\mathrm{K}^{+}$ratio in a test substance can predict the modes of the diuretic mechanism of the CAIs effect [38]. If the $\mathrm{Cl}^{-} / \mathrm{Na}^{+}+\mathrm{K}^{+}$ratio is between 0.8 and 1.00 , it excludes the CAI effect, but if below 0.8 , it is considered to have strong CAI activity [31]. In this study, excluding the AF and CF, both the HME and EAF showed a strong CAI effect. This indicates that these fractions possibly have a different diuretic mode of action.

Collectively, the diuretic activity of the HME and its EAF was found to be highly potent when compared to the CF and AF. This indicates that the pharmacologically active ingredient(s) of the root bark of $C$. myricoides might have better solubility nature in the $80 \%$ methanol and better fractionated by ethyl acetate than other solvents used. Moreover, the results indicated that the diuretic activity of the HME is found to be higher than all fractions and comparable with a single oral dose $(10 \mathrm{mg} / \mathrm{kg})$ of furosemide. This might be due 
TABLE 3: The effect of the hydromethanolic extract and solvent fractions of the root bark of Clerodendrum myricoides on urine electrolyte in rats.

\begin{tabular}{|c|c|c|c|c|c|c|c|c|}
\hline \multirow{2}{*}{ Dose $(\mathrm{mg} / \mathrm{kg})$} & \multicolumn{3}{|c|}{${ }^{*}$ Urine electrolyte $(\mathrm{mmol} / \mathrm{l})$} & \multicolumn{3}{|c|}{ Saliuretic index } & \multirow{2}{*}{$\mathrm{Na}^{+} / \mathrm{K}^{+}$} & \multirow{2}{*}{$\mathrm{Cl}^{-} / \mathrm{Na}^{+}+\mathrm{K}^{+}$} \\
\hline & $\mathrm{Na}^{+}$ & $\mathrm{K}^{+}$ & $\mathrm{Cl}^{-}$ & $\mathrm{Na}^{+}$ & $\mathrm{K}^{+}$ & $\mathrm{Cl}^{-}$ & & \\
\hline HME400 & $85.33 \pm 8.30$ & $66.38 \pm 14.77^{\mathrm{b} 2, \mathrm{~d} 2}$ & $106.83 \pm 10.27^{\mathrm{b} 3}$ & 0.88 & 0.59 & 0.77 & 1.28 & 0.70 \\
\hline HME200 & $121.16 \pm 7.60$ & $124.18 \pm 6.34$ & $181.83 \pm 7.52^{\mathrm{c} 3, \mathrm{~d} 1, \mathrm{e} 1}$ & 1.26 & 1.11 & 1.31 & 0.97 & 0.74 \\
\hline HME100 & $87.66 \pm 16.49$ & $89.11 \pm 7.44$ & $114.66 \pm 11.60$ & 0.90 & 0.80 & 0.80 & 0.98 & 0.64 \\
\hline AF400 & $151.16 \pm 15.09$ & $192.50 \pm 24.05^{\mathrm{b} 2, \mathrm{c} 2, \mathrm{~d} 1, \mathrm{e} 2}$ & $369.66 \pm 36.74^{\mathrm{b3}, \mathrm{c} 3, \mathrm{~d} 3, \mathrm{e} 3}$ & 1.56 & 1.73 & 2.67 & 0.78 & 1.07 \\
\hline AF200 & $116.33 \pm 16.50$ & $110.55 \pm 13.85$ & $164.33 \pm 20.72$ & 1.20 & 0.99 & 1.18 & 1.05 & 0.72 \\
\hline AF100 & $137.33 \pm 15.72$ & $102.66 \pm 7.22$ & $204.16 \pm 14.85$ & 1.42 & 0.92 & 1.47 & 1.33 & 0.85 \\
\hline EAF400 & $137.83 \pm 4.84^{\mathrm{d} 1, \mathrm{e} 1}$ & $114.31 \pm 8.75$ & $172.50 \pm 5.61$ & 1.36 & 1.01 & 1.27 & 1.20 & 0.68 \\
\hline EAF200 & $146.83 \pm 7.66^{\mathrm{d} 2, \mathrm{e} 2}$ & $110.53 \pm 9.56$ & $175.66 \pm 8.72$ & 1.45 & 0.98 & 1.29 & 1.33 & 0.68 \\
\hline EAF100 & $122.33 \pm 7.51$ & $126.45 \pm 7.40$ & $229.66 \pm 27.97^{\mathrm{d} 2, \mathrm{e} 1}$ & 1.21 & 1.12 & 1.69 & 0.96 & 0.92 \\
\hline CF400 & $143.33 \pm 8.38^{\mathrm{b} 3, \mathrm{e} 1}$ & $166.75 \pm 7.74^{\mathrm{b} 3, \mathrm{c} 2, \mathrm{e} 2}$ & $287.00 \pm 35.24^{\mathrm{b} 3, \mathrm{~d} 3, \mathrm{e} 3}$ & 1.43 & 1.48 & 2.11 & 0.85 & 0.92 \\
\hline CF200 & $72.16 \pm 13.77^{\mathrm{cl}}$ & $74.40 \pm 12.15^{\mathrm{d} 2}$ & $119.16 \pm 23.22^{\mathrm{c} 2}$ & 0.71 & 0.66 & 0.87 & 0.96 & 0.81 \\
\hline CF100 & $119.66 \pm 6.75$ & $107.73 \pm 6.23$ & $242.33 \pm 14.16^{\mathrm{d} 1, \mathrm{e} 2}$ & 1.18 & 0.96 & 1.78 & 1.11 & 1.06 \\
\hline F10 & $102.66 \pm 13.13$ & $129.58 \pm 17.04$ & $140.83 \pm 11.74$ & 1.01 & 1.15 & 1.03 & 0.79 & 0.60 \\
\hline DW & $96.50 \pm 0.67$ & $110.88 \pm 3.89$ & $138.33 \pm 3.89$ & - & - & - & 0.87 & 0.67 \\
\hline $2 \% \mathrm{TDW}$ & $100.83 \pm 2.89$ & $112.16 \pm 4.33$ & $135.66 \pm 6.18$ & - & - & - & 0.89 & 1.59 \\
\hline
\end{tabular}

${ }^{*}$ Results are expressed as mean \pm SEM $(n=6)$. Compared to HME: hydromethanolic extract $\left({ }^{\mathrm{a}} 400,{ }^{\mathrm{b}} 200,{ }^{\mathrm{c}} 100 \mathrm{mg} / \mathrm{kg}\right)$; compared to AF: aqueous fraction $\left({ }^{\mathrm{a}} 400,{ }^{\mathrm{b}} 200,{ }^{\mathrm{c}} 100 \mathrm{mg} / \mathrm{kg}\right)$; ${ }^{\mathrm{d}}$ compared to F10: furosemide $10 \mathrm{mg} / \mathrm{kg}$; ${ }^{\mathrm{e}}$ compared to DW: distilled water; compared to EAF: ethyl acetate fraction ( ${ }^{\mathrm{a}} 400$, ${ }^{\mathrm{b}} 200$, $\left.{ }^{c} 100 \mathrm{mg} / \mathrm{kg}\right) ;$ compared to CF: chloroform fraction $\left({ }^{\mathrm{a}} 400,{ }^{\mathrm{b}} 200,{ }^{\mathrm{c}} 100 \mathrm{mg} / \mathrm{kg}\right) ;{ }^{\mathrm{d}}$ compared to F10: furosemide $10 \mathrm{mg} / \mathrm{kg}$; ${ }^{\mathrm{e}}$ compared to $2 \%$ TDW: $2 \%$ Tween 80 in distilled water. ${ }^{1} \mathrm{P}<0.05 ;{ }^{2} \mathrm{P}<0.01 ;{ }^{3} \mathrm{P}<0.001$. Saliuretic index $=\mathrm{Na}^{+}, \mathrm{K}^{+}, \mathrm{Cl}^{-}$of the test group $/ \mathrm{Na}^{+}, \mathrm{K}^{+}, \mathrm{Cl}^{-}$of the control group; natriuretic index $=\mathrm{Na}^{+} / \mathrm{K}^{+}$ and $\mathrm{CAI}$ index $=\mathrm{Cl}^{-} / \mathrm{Na}^{+}+\mathrm{K}^{+}$in the same group.

TABLE 4: The effect of the hydromethanolic extract and solvent fractions of the root bark of Clerodendrum myricoides on serum electrolyte in rats.

\begin{tabular}{|c|c|c|c|}
\hline \multirow{2}{*}{ Dose $(\mathrm{mg} / \mathrm{kg})$} & \multicolumn{3}{|c|}{${ }^{*}$ Serum electrolyte $(\mathrm{mmol} / \mathrm{l})$} \\
\hline & $\mathrm{Na}^{+}$ & $\mathrm{K}^{+}$ & $\mathrm{Cl}^{-}$ \\
\hline HME400 & $135.00 \pm 4.29^{\mathrm{c} 2, \mathrm{~d} 1, \mathrm{e} 1}$ & $12.75 \pm 3.19^{\mathrm{b} 1, \mathrm{c} 2, \mathrm{~d} 2}$ & $93.50 \pm 2.84^{\mathrm{c} 3, \mathrm{~d} 2, \mathrm{e} 2}$ \\
\hline HME200 & $142.00 \pm 1.63$ & $5.41 \pm 0.16$ & $99.00 \pm 1.29$ \\
\hline HME100 & $147.66 \pm 0.55$ & $5.10 \pm 0.07$ & $103.16 \pm 0.40$ \\
\hline AF400 & $146.33 \pm 0.98$ & $4.46 \pm 0.29^{\mathrm{e} 3}$ & $102.50 \pm 0.76$ \\
\hline AF200 & $147.83 \pm 0.87^{\mathrm{e} 1}$ & $4.26 \pm 0.07^{\mathrm{e} 3}$ & $102.66 \pm 0.71$ \\
\hline AF100 & $148.00 \pm 0.63^{\mathrm{e} 2}$ & $3.96 \pm 0.14^{\mathrm{d} 1, \mathrm{e} 3}$ & $104.33 \pm 0.84$ \\
\hline EAF400 & $148.16 \pm 0.40$ & $4.48 \pm 0.18^{\mathrm{e} 2}$ & $101.00 \pm 0.36$ \\
\hline EAF200 & $145.00 \pm 2.19$ & $6.03 \pm 0.58^{\mathrm{c} 2}$ & $104.00 \pm 1.23$ \\
\hline EAF100 & $150.83 \pm 2.18^{\mathrm{e} 1}$ & $4.08 \pm 0.08^{\mathrm{e} 3}$ & $104.33 \pm 1.22$ \\
\hline CF400 & $149.83 \pm 1.51^{\mathrm{d} 2, \mathrm{e} 2}$ & $5.25 \pm 0.47$ & $102.83 \pm 1.16$ \\
\hline CF200 & $149.00 \pm 0.85^{\mathrm{d} 2, \mathrm{e} 1}$ & $3.98 \pm 0.11^{\mathrm{e} 3}$ & $100.66 \pm 0.55$ \\
\hline CF100 & $146.16 \pm 0.47$ & $4.03 \pm 0.09^{\mathrm{e} 3}$ & $101.83 \pm 0.16$ \\
\hline F10 & $145.16 \pm 0.79$ & $5.18 \pm 0.15$ & $101.83 \pm 0.30$ \\
\hline DW & $144.00 \pm 0.36$ & $7.06 \pm 0.53$ & $101.83 \pm 0.47$ \\
\hline $2 \% \mathrm{TDW}$ & $144.33 \pm 0.33$ & $6.50 \pm 0.55$ & $102.16 \pm 0.47$ \\
\hline
\end{tabular}

${ }^{*}$ Results are expressed as mean \pm SEM $(n=6)$. Compared to HME: hydromethanolic extract $\left({ }^{\mathrm{a}} 400,{ }^{\mathrm{b}} 200,{ }^{\mathrm{c}} 100 \mathrm{mg} / \mathrm{kg}\right)$; compared to AF: aqueous fraction $\left({ }^{\mathrm{a}} 400,{ }^{\mathrm{b}} 200,{ }^{\mathrm{c}} 100 \mathrm{mg} / \mathrm{kg}\right) ;{ }^{\mathrm{d}}$ compared to F10: furosemide $10 \mathrm{mg} / \mathrm{kg}$; ${ }^{\mathrm{e}}$ compared to DW: distilled water; compared to EAF: ethyl acetate fraction ( ${ }^{\mathrm{a}} 400$, ${ }^{\mathrm{b}} 200$, ${ }^{c} 100$ ); compared to CF: chloroform fraction ( ${ }^{\mathrm{a}} 400,{ }^{\mathrm{b}} 200,{ }^{\mathrm{c}} 100 \mathrm{mg} / \mathrm{kg}$ ); ${ }^{\mathrm{d}}$ compared to F10: furosemide $10 \mathrm{mg} / \mathrm{kg}$; ${ }^{\mathrm{e}}$ compared to $2 \%$ TDW: $2 \%$ Tween 80 in distilled water. ${ }^{1} P<0.05 ;{ }^{2} P<0.01 ;{ }^{3} P<0.001$.

to the fact that the crude extract (HME) contains more pharmacologically active ingredient(s) and might act synergistically [39].

It was previously stated to contain flavonoids, terpenoids, phenols, glycosides, tannins, and saponins from the root part of the plant [14]. Diuretic activities of these detected constituents were studied in several previously conducted efficacies of plant-based studies, and their marked diuretic effects were reported [40-46]. As a result, the presence of the mentioned and other constituents might be coextracted components that could partly be responsible for the observed diuresis, natriuretic, and saliuretic activities of the root bark of C. myricoides $[47,48]$.

Regarding the safety profile of the plant, the HME and all solvent fractions of the experimental plant did not appear to have any physically visible signs and histological toxicity, as well as no death was recorded up to the dose of $2000 \mathrm{mg} / \mathrm{kg}$ of 14 days follow-up. Besides, no sign of toxicity and death was recorded during the diuretic activity study period. 


\section{Conclusion}

The present study revealed that the rats treated with HME and EAF of the root bark of C. myricoides showed significantly delayed onset and dose-dependent prolonged diuresis, natriuretic effect, and CAIs effect. Both the medium and highest test doses of the HME showed remarkable diuresis. This could partly explain the traditionally claimed uses of C. myricoides as a diuretic agent. The CF produced lesser diuresis, while the AF devoid to show significant diuresis, but both showed the saliuretic effect at larger test dose. The HME and all of the solvent fractions were found to be safe up to $2000 \mathrm{mg} / \mathrm{kg}$. However, further studies are required to isolate, purify, structurally elucidate, and propose the possible mechanisms of diuretic action and to assess the long-term efficacy as well as safety profile.

\section{Data Availability}

The data used to support the findings of this study are available from the corresponding author upon request.

\section{Conflicts of Interest}

The authors declare that they have no conflicts of interest.

\section{References}

[1] B. V. Bharat, "Comparative diuretic study of medicinal plants in individual and combination form," Magazine.Pharmatutor.Org. vol. 5, no. 4, pp. 42-45, 2017.

[2] A. Husain, D. Madhesia, M. Rashid, A. Ahmad, and S. A. Khan, "Synthesis and in vivo diuretic activity of some new benzothiazole sulfonamides containing quinoxaline ring system," Journal of Enzyme Inhibition and Medicinal Chemistry, vol. 31, no. 6, pp. 1682-1689, 2016.

[3] D. H. Ellison, "Clinical Pharmacology in diuretic use," Clinical Journal of the American Society of Nephrology, vol. 14, pp. 1-10, 2019.

[4] D. Wile, "Diuretics: a review," Annals of Clinical Biochemistry, vol. 49, no. 5, pp. 419-431, 2012.

[5] J.-C. Trullas, J. Casado, J.-L. Morales-Rull et al., "Prevalence and outcome of diuretic resistance in heart failure," Internal and Emergency Medicine, vol. 14, no. 4, pp. 529-537, 2019.

[6] E. F. Carrizales-Sepulveda, R. Vera-Pineda, R. A. JimenezCastillo, M. A. Benavides-Gonzalez, and A. Ordaz-Farias, "Prevalence and outcome of diuretic resistance in heart failure: comment," Internal and Emergency Medicine, vol. 14, no. 4, pp. 631-632, 2019.

[7] M. Demoz, K. P. Gachoki, K. Gachoki, K. Mungai, and B. Negusse, "Ethnobotanical survey and preliminary phytochemical studies of plants traditionally used for diabetes in Eritrea," European Journal of Medicinal Plants, vol. 9, no. 2, pp. 1-11, 2015.

[8] A. Teklay, B. Abera, and M. Giday, "An ethnobotanical study of medicinal plants used in Kilte Awulaelo district, Tigray region of Ethiopia," Journal of Ethnobiology and Ethnomedicine, vol. 9, no. 65, pp. 1-23, 2013.

[9] N. Shrivastava, T. Patel, C. Maxim, B. Thomas, C. Gurke, and C. G. Don, "Clerodendrum and heathcare : an overview," Med Medicinal and Aromatic Plant Science and Biotechnology, vol. 1, no. 1, pp. 142-150, 2007.
[10] A. E. Al-snafi, "Chemical constituents and pharmacological effects of clerodendrum inerme- a review," SMU Medical Journ al, vol. 1604, no. 1, pp. 129-154, 2016.

[11] T. Deressa, Y. Mekonnen, and A. Animut, "In vivo antimalarial activities of clerodendrum myricoides, dodonea angustifolia and aloe debrana against plasmodium berghei," Ethiopian Journal of Health Development, vol. 24, no. 1, pp. 1-5, 2010.

[12] A. Sileshi, T. Gebre-Mariam, and K. Asres, "Antibacterial and antifungal activities of extracts of some medicinal plants of Ethiopia," Ethiopian Pharmaceutical Journal, vol. 25, pp. 111-120, 2007.

[13] A. Tadele, "Ethiopian herbal medicine research article profile," in Ethiopian Public Health Institute, pp. 1-343, 2017.

[14] H. Esatu, I. Alemayehu, E. Haile, S. Tadesse, A. Dekebo, and M. Endale, "Phenolic glycosides from roots of clerodendrum myricoides," American Journal of Essential Oils and Natural Products, vol. 3, no. 1, pp. 1-6, 2015.

[15] Y. Tilahun, "Ethnobotanical study of traditional medicinal plants used in and around Adigrat town, eastern Tigray, Ethiopia," Journal of Medicinal Plants Studies, vol. 6, no. 4, pp. 11-19, 2018.

[16] M. S. Pallie, P. K. Perera, C. L. Goonasekara, K. M. N. Kumarasinghe, and L. D. A. M. Arawwawala, "Evaluation of diuretic effect of the hot water extract of standardized tragia involucrata Linn., in rats," International Journal of Pharmacology, vol. 13, no. 1, pp. 83-90, 2017.

[17] OECD-425, Test No. 425: Acute Oral Toxicity: Procedure, OECD Publishing, Paris, France, 2008.

[18] M. Asif, Q. Jabeen, A. Malik, S. Abdul, and M. Atif, "Diuretic activity of aqueous extract of nigella sativa in albino rats," Acta Poloniae Pharmaceutica, vol. 72, no. 1, pp. 129-135, 2015.

[19] S. Sarfaraz and R. Najam, "Evaluation of diuretic and saliuretic potential of beta vulgaris (beet root) at different doses," Indian Journal of Pharmaceutical Education and Research, vol. 52, no. 2, pp. 248-254, 2018.

[20] W. L. Lipschitz, Z. Hadidian, and A. Kerpcsar, "Bioassay of diuretics," Journal of Pharmacology and Experimental Therapeutics, vol. 79, no. 2, pp. 97-110, 1943.

[21] S. T. Kau, J. R. Keddie, and D. Andrews, "A method for screening diuretic agents in the rat," Journal of Pharmacological Methods, vol. 11, no. 1, pp. 67-75, 1984.

[22] P. G. Prathibhakumari, "A comparative study on the diuretic activity of neolamarckia cadamba," International Research Journal of Pharmacy, vol. 8, no. 12, pp. 55-61, 2018.

[23] M. Asif, Q. Jabeen, M. Atif, A. Malik, S. Abdul, and M. Qamar-uz-zaman, "Diuretic activity of achyranthes aspera Linn crude aqueous extract in albino rats," Tropical Journal of Pharmaceutical Research, vol. 13, no. 12, pp. 2039-2045, 2014.

[24] D. Prakash, M. C. Bindal, S. K. Gupta, and A. K. Gupta, "Evaluation of diuretic activity of milk extract of semecarpus anacardium nut," International Research Journal of Pharmacy, vol. 4, no. 3, pp. 170-173, 2013.

[25] S. Parasuraman, R. Raveendran, and R. Kesavan, "Blood sample collection in small laboratory animals," Journal of Pharmacology and Pharmacotherapeutics, vol. 1, no. 2, pp. 87-93, 2010.

[26] M. Compaore, A. Lamien-Meda, C. Mogosan et al., "Antioxidant, diuretic activities and polyphenol content ofStereospermum kunthianumCham. (Bignoniaceae)," Natural Product Research, vol. 25, no. 19, pp. 1777-1788, 2011.

[27] S. Kebamo, "Evaluation of diuretic activity of different solvent fractions of methanol extract of carissa edulis root bark in rats," Med Chem (Los Angeles), vol. 5, no. 11, pp. 472-478, 2015. 
[28] S. A. Deraniyagala, W. D. Ratnasooriya, and S. S. Wijetunge, "Oral diuretic activity of water extract of ricinus communis leaves in rats," International Journal of Institutional Pharmacy and Life Sciences, vol. 3, no. 4, pp. 2249-6807, 2013.

[29] W. D. Alexander, R. A. Branch, D. F. Levine, and M. Hartog, "The urinary sodium: potassium ratio and response to diuretics in resistant oedema," Postgraduate Medical Journal, vol. 53, no. 617, pp. 117-121, 1977.

[30] P. Shanmuganathan and M. Kumarappan, "Evaluation of diuretic, saluretic and natriuretic activity of hydrochlorothiazide in combination with misoprostol in wistar rats," National Journal of Physiology, Pharmacy and Pharmacology, vol. 8, no. 9, pp. 1226-1229, 2018.

[31] L. H. Lacorte, J. L. Ang, D. Ferrer et al., "Diuretic activity of kalumpang (stercula foetida L) methanolic leaf extract in male albino Sprague Dawley rats," Asian Journal of Biological and Life Sciences, vol. 7, no. 2, pp. 33-39, 2018.

[32] A. K. Durairaj, U. Kanti Mazumder, M. Gupta, and S. Kumar Ray, "Effects of methanolic extract of oxystelma esculentum on diuresis and urinary electrolytes excretion in rats," Iranian Journal of Pharmacology and Therapeutics [Internet], vol. 6, no. 2, pp. 207-211, 2007.

[33] B. Geleta, M. E. Belete, N. Fekadu, F. Challa, and T. S. Pathways, "Evaluation of diuretic activity of hydroethanolic extract of moringa stenopetala leaves in swiss albino mic," Clinical and Experimental Pharmacology and Physiology, vol. 5, no. 5, pp. 1-5, 2015.

[34] A. Tegegne, B. Mishra, and M. Geta, "Evaluation of in vivo diuretic activity of methanolic extracts of clutia abyssinica (euphorbiaceae) roots in wistar albino rats," Annals of Internal Medicine, vol. 1, no. 8, pp. 1-9, 2017.

[35] W. Hailu and E. Engidawork, "Evaluation of the diuretic activity of the aqueous and $80 \%$ methanol extracts of ajuga remota benth (lamiaceae) leaves in mice," BMC Complementary and Alternative Medicine, vol. 14, no. 135, pp. 1-8, 2014.

[36] P. I. A. de Bruijn, C. K. Larsen, S. Frische et al., "Furosemideinduced urinary acidification is caused by pronounced $\mathrm{H}+$ secretion in the thick ascending limb," American Journal of Physiology-Renal Physiology, vol. 309, no. 2, pp. F146-F153, 2015.

[37] A. E. Melka, E. Makonnen, A. Debella, N. Fekadu, and B. Geleta, "Diuretic activity of the aqueous crude extract and solvent fractions of the leaves of Thymus serrulatus in mice," Journal of Experimental Pharmacology, vol. 8, pp. 61-67, 2016.

[38] A. E. Melka, E. Makonnen, A. Debella, N. Fekadu, and B. Geleta, "Evaluation-of-diuretic-activity-of-methanolcrude-extract-of-thymus-serrulatus-leaves-and-its-solventfraction-in-mice," Biology and Medicine, vol. 8, no. 7, pp. 1-6, 2016.

[39] B. S. Nayak, S. C. Dinda, and P. Ellaiah, "Evaluation of diuretic activity of gmelina arborea roxb. fruit extracts bhabani," Journal of Pharmaceutical and Clinical Research, vol. 6, no. 1, pp. 111-113, 2013.

[40] V. K. Gupta and V. Arya, "A review on potential diuretics of Indian medicinal plants," Journal of Chemical and Pharmaceutical Research, vol. 3, no. 1, pp. 613-620, 2011.

[41] L. R. L. Diniz, V. G. Portella, F. M. Cardoso et al., "The effect of saponins from ampelozizyphus amazonicus ducke on the renal $\mathrm{Na}+$ pumps' activities and urinary excretion of natriuretic peptides," BMC Complementary and Alternative Medicine, vol. 12, no. 40, pp. 1-7, 2012.

[42] K. Hullatti, J. R. Manjunatha, and I. J. Kuppasth, "Comparative study on diuretic effect of buchanania angustifolia roxb., and buchanania lanzan spreng. Fruit extracts and fractions," Journal of Applied Pharmaceutical Science, vol. 4, no. 8, pp. 59-63, 2014.

[43] N. Yuliana, A. Khatib, A. Link-Struensee et al., "Adenosine A1Receptor binding activity of methoxy flavonoids fromOrthosiphon stamineus," Planta Medica, vol. 75, no. 02, pp. 132-136, 2009.

[44] U. Patel, M. Kulkarni, V. Undale, and A. Bhosale, "Evaluation of diuretic activity of aqueous and methanol extracts of Lepidium sativum Garden Cress (Cruciferae) in rats," Tropical Journal of Pharmaceutical Research, vol. 8, no. 3, pp. 215-219, 2009.

[45] M. Perez, M. A. Boffill, F. J. Moron, M. L. Sueiro, E. Marrero, and E. Betancourt, "Ethnopharmacological and preclinical study of diuretic activity in medicinal and food plants used by Cuban population," Emirates Journal of Food and Agriculture, vol. 23, no. 3, pp. 214-221, 2011.

[46] H. Jouad, M. A. Lacaille-Dubois, B. Lyoussi, and M. Eddouks, "Effects of the flavonoids extracted from spergularia purpurea pers. On arterial blood pressure and renal function in normal and hypertensive rats," Journal of Ethnopharmacology, vol. 76, no. 2, pp. 159-163, 2001.

[47] T. Nedi, N. Mekonnen, and K. Urga, "Diuretic effect of the crude extracts of Carissa edulis in rats," Journal of Ethnopharmacology, vol. 95, no. 1, pp. 57-61, 2004.

[48] G. D. Kanias, A. Loukis, and S. M. Philianos, "Trace element pharmacognostical study on diuretic drugs by neutron activation analysis," Journal of Radioanalytical Chemistry, vol. 54, no. 1-2, pp. 103-112, 1979. 